\title{
Comparism of Adsorption Behaviour of Caryota Rumphiana Flower and Goat Hooves to Lead and Manganese Ions in Aqueous Solution
}

\author{
Egila J.N ${ }^{1}$, Jimoh T. $\mathbf{O}^{2, *}$, Ifunanya G. ${ }^{1}$, Dayo $\mathbf{O}^{1}$ \\ ${ }^{1}$ Department of Chemistry, University of Jos, Plateau State, Nigeria \\ ${ }^{2}$ Department of Chemistry, Federal University of Technology, Minna, Niger State, Nigeria \\ jimohishola8@gmail.com
}

\begin{abstract}
The adsorption of $\mathrm{Pb}^{2+}$ and $\mathrm{Mn}^{2+}$ ions by cellulosic (Caryota rumphiana flower) and keratinous (Goat hooves) materials was investigated in order to compare their adsorptive capability. The experiments were carried out by batch method at $30^{\circ} \mathrm{C}$ and the effect of initial metal ion concentrations and contact time were evaluated. $\mathrm{Pb}^{2+}$ and $\mathrm{Mn}^{2+}$ ions attained equilibrium within 60 and 120 minutes respectively for both cellulosic and keratinous material. The equilibrium data fitted the Freundlich adsorption isotherm. This study demonstrated that Caryota rumphiana flower and Goat hooves could be used as an alternative adsorbent to remove $\mathrm{Pb}^{2+}$ and $\mathrm{Mn}^{2+}$ ions from aqueous solution.
\end{abstract}

Keywords Caryota Rumphiana, Goat Hooves, Adsorption, Lead, Manganese, Contact Time

\section{Introduction}

The continuous increase in the level of heavy metal $\mathrm{d}$ is charge into the environment posed serious threat not only to human health but the entire ecosystem[1]. Heavy metals are nonbiodegrable and thus persist in the environment. Therefore, the concentration of these metals must be reduced to acceptable levels before being discharged into environment.

Several conventional treatment technologies had been designed to remove or at least reduced the concentration of these toxic metals from aqueous solution, but most of them were not economical, in most cases are very expensive for developing country like Nigeria, as a result of high cost of treatment associated with wastewater. This necessitated the search for low cost adsorbents that have been reported to be environmental friendly. The use of agricultural and animal wastes for the removal of toxic and valuable heavy metals from waste water has continued to attract a lot of attention, principally because they are easily available and at no cost, and more importantly because they are capable of binding heavy metals by adsorption, chelation and ion exchange.

In addition, several agricultural and agricultural bye products, animal wastes and industrial by-products have been reported as an alternative to high cost activated charcoal[2-5]. Cellu lose materials such as saw dust[6], tobacco

* Corresponding author:

jimohishola8@gmail.com (Jimoh T. O)

Published online at http://journal.sapub.org/ajee

Copyright (C) 2012 Scientific \& Academic Publishing. All Rights Reserved
Dust[7], water leaf[8] Hevea bransilensis bark[9] and Keratinous material like Periwinkle shell[10] have been used to study heavy metals uptake from aqueous solutions. Caryota rumphiana flower beautify the environment, the beautiful flowers later turn into waste which constituted environmental nuisance as a result of lack of proper disposal, so also the goat hooves.

But there is no information on the comparative studies on Caryota rumphiana flower and goat hooves. Therefore, the objective of this work is to compare adsorption behaviour of Caryota rumphiana flower and goat hooves to lead and manganese ions in aqueous solution.

\section{Materials and Methods}

\subsection{Sample Collection}

The Caryota rumphiana flowers were collected from a garden in Ahmadu Bello University, Zaria and while the goat hooves were randomly collected within Jos Metropolis. They were washed with deionized water and later air-dried. The samples were individually ground to powdered form by mortar and pestle. The samples were then sieved through a 125 and $250 \mu \mathrm{m}$ mesh size. The sample that was retained on $250 \mu \mathrm{m}$ mesh size was used for sorption studies.

\subsection{Aqueous Solution Preparation}

Aqueous solution containing $\mathrm{Pb}^{2+}$ and $\mathrm{Mn}^{2+}$ ions were prepared from $\mathrm{Pb}\left(\mathrm{NO}_{3}\right)_{2}$ and $\mathrm{MnSO}_{4} \cdot \mathrm{H}_{2} \mathrm{O} .1000 \mathrm{mg} / \mathrm{L}$ stock solutions of each of the salts were prepared. Other concen- 
trations of $10,20,30,40$ and $50 \mathrm{mg} \mathrm{L}^{-1}$ were obtained from this stock solution by serial dilution. Fresh dilutions were used for each experiment. The $\mathrm{pH}$ of the aqueous solution was adjusted to a pH 5 using either $0.5 \mathrm{M} \mathrm{NaOH}$ and $0.5 \mathrm{M}$ $\mathrm{HCl}$ to prevent hydrolys is. The concentration of metal ions in aqueous solution was analyzed by Inductive Coupled Plas ma- Optical Emission Spectrometer.

\subsection{Adsorption Experiments}

Batch studies carried out included time dependence and initial metal ion concentration dependence. The experiment was jointly carried out at the Chemistry Department of University of Jos, Plateau State, Nigeria as well as Chemistry Department of Federal University of Technology, Minna, Niger State, and Nigeria.

\subsection{Effect of Sorption Time}

$0.5 \mathrm{~g}$ sample each of cellulosic and keratinous material was taken and shaken with $100 \mathrm{~cm}^{3}$ of a metal ion solution whose concentration was $5 \mathrm{mg} \mathrm{dm}^{-3}$. The bottles were shaken at various time intervals of 30 to 180 minutes at room temperature in a reciprocating shaker at $300 \mathrm{rpm}$. At the end of each contact period, the mixture was filtered using Whatman filter paper No. 42 and the filtrate was analyzed using the ICP-OES. The difference between the initial and final metal ion concentration was recorded as the amount of metal ion bound by the substrate.

\subsection{Batch Adsorption Study}

The equilibrium sorption was carried out at $30^{\circ} \mathrm{C}$ using a concentration range of $10-50 \mathrm{mg} \mathrm{d} \mathrm{m}^{-3} .0 .5 \mathrm{~g}$ of the substrates was weighed into a $250 \mathrm{~cm}^{3}$ conical flask and $100 \mathrm{~cm}^{3}$ of the metal ion solution was measured into each conical flask containing the substrates. The conical flask was shaken for 90 minutes at roo $\mathrm{m}$ temperature in a reciprocating shaker at $300 \mathrm{rpm}$. The substrates were removed from the mixture by filtration and the concentration of the residual ions in the solution was determined. The a mount of metal ions adsorbed from solution was determined by difference.

\subsection{Results}

\section{Discussion}

The variation in the amount of metal ion bound to the substrates with contact time is shown in Figure 1 to 4 . For Cryota rumphiana flower, $\mathrm{Pb}^{2+}$ and $\mathrm{Mn}^{2+}$ ions reached equilibrium at 60 and 120 minutes respectively, with amount adsorbed by the substrate at $58.15 \mathrm{mg} / \mathrm{L}$ for $\mathrm{Pb}^{2+}$ ion and $36.61 \mathrm{mg} / \mathrm{L}$ for $\mathrm{Mn}^{2+}$ ion. One interesting thing about this result was that the equilibriumtime of adsorption by the Goat hooves material was the same as that of the cellulosic material, with the difference being in the a mount adsorbed by the substrates. It was observed that after the equilibrium, the amount adsorbed by the substrates decreases steadily and this could plausibly be due to the fact that the binding sites on the substrates were exhausted and further shaking only resulted in desorption[10].

In addition,[11] had earlier observed that in the multimetal sorption, the metal ions compete for the adsorption sites on the adsorbent. This competition affects the diffusion properties of the metal ions, hence decreases the amount of the metal ions removed. Thus, the metal ion that successfully reaches the adsorption site faster depends on the ionic radii and metal ion types. Competition among the metal ions for adsorption sites obviously affected the uptake level of metal ions. Based on these fundamental facts, the adsorption process was faster and more efficient for $\mathrm{Pb}^{2+}$ ion than for $\mathrm{Mn}^{2+}$ ion in both substrates. This was probably due to the size of the ions like $\mathrm{Pb}^{2+}$ ion which became s maller than $\mathrm{Mn}^{2+}$ ion when hydrated and as such is less susceptible to stearic hindrance. This significantly enhances their chances of being adsorbed to the reactive sites because the heavily hydrated ions migrate slowly in aqueous solutions. This might be the reas on why more of $\mathrm{Pb}^{2+}$ ion was able to adsorb than $\mathrm{Mn}^{2+}$ ion. This observation is in agreement with the works of[8] and[12].

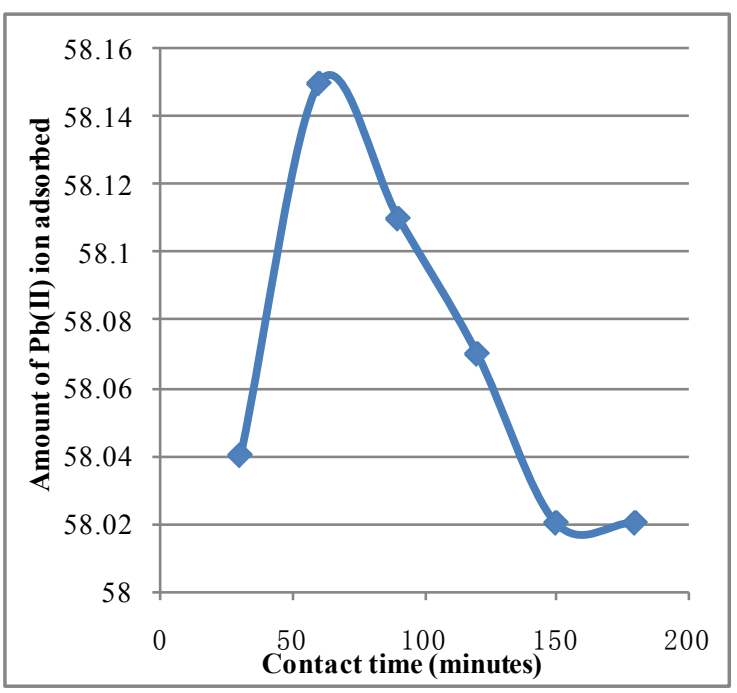

Figure 1. Effect of variation of contact time on the adsorption of $\mathrm{Pb}^{2+}$ ion on Caryota numphiana flower at $30^{\circ} \mathrm{C}$. The contact time was established within 60 minutes

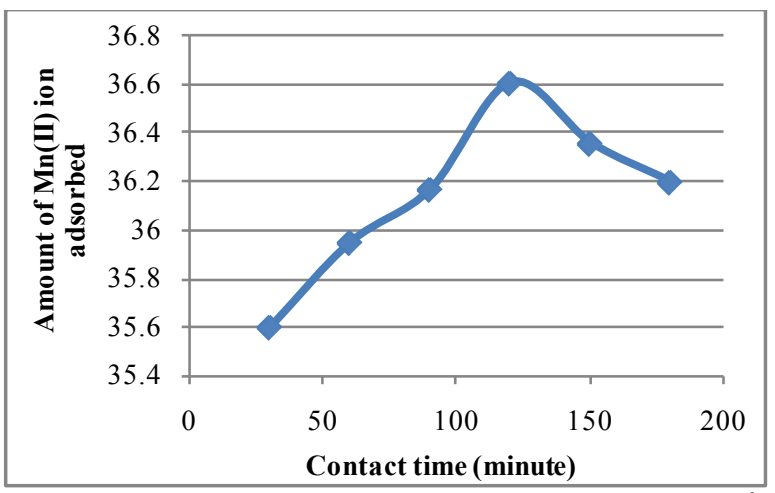

Figure 2. Effect of variation of cont act time on the adsorption of $\mathrm{Mn}^{2+}$ ion Caryota numphiana flower at $30^{\circ} \mathrm{C}$. The contact time was established within 120 minutes 


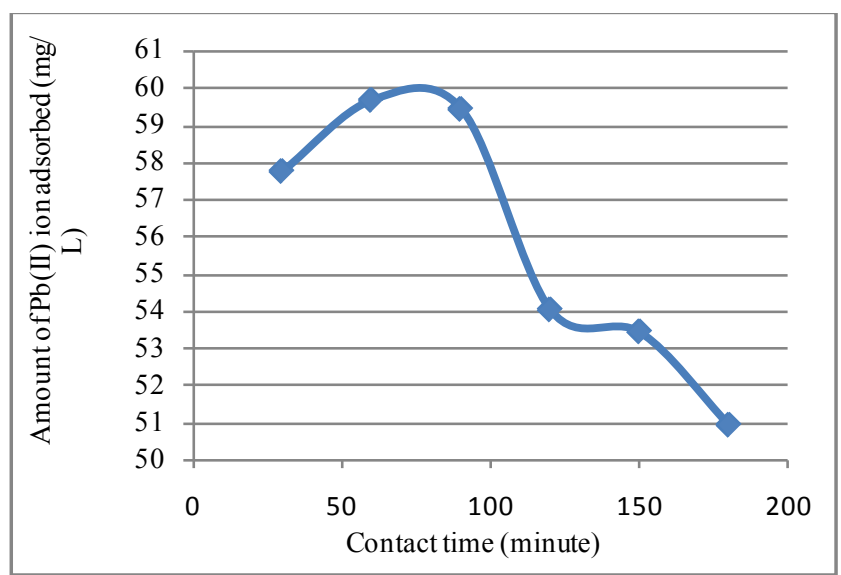

Figure 3. Effect of variation of contact time on the adsorption of $\mathrm{Pb}^{2+}$ ion Goat hooves at $30^{\circ} \mathrm{C}$. The equilibrium time between the adsorbent and the adsorbate was 60 minutes

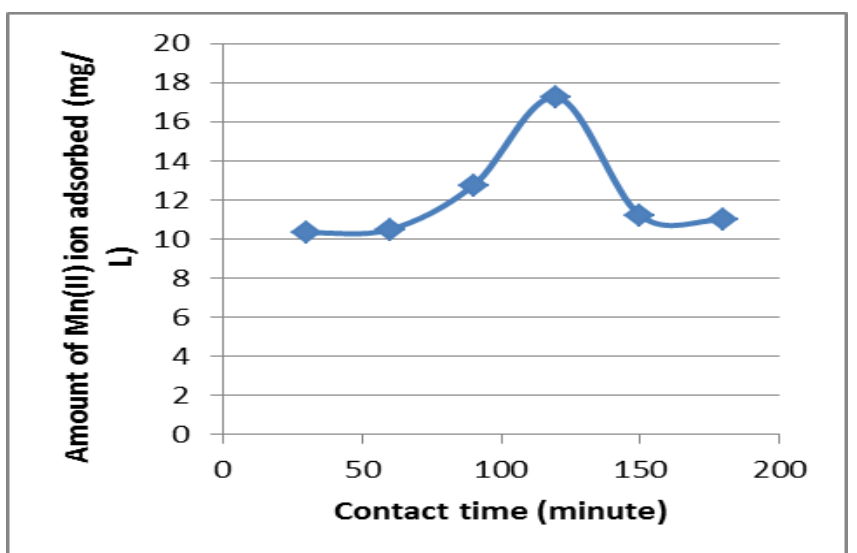

Figure 4. Effect of variation of contact time on the adsorption of $\mathrm{Mn}^{2+}$ ion Goat hooves at $30^{\circ} \mathrm{C}$. The equilibrium time between the adsorbent and the adsorbate was 120 minutes

The variation in the amount of metal ion bound to the substrate with increasing concentration is illustrated in Figure 5 and 6 . It was observed that as the concentration increased, a corresponding increase was recorded for the amount of $\mathrm{Pb}^{2+}$ ion adsorbed by the Caryota rumphiana flower than the amount of $\mathrm{Mn}^{2+}$ ion removed. This might be explained on the basis that at higher concentration levels, there was an increase in the number of metal ion competing for available binding sites on the substrate. This finding is in agreement with the work of $[8,13]$. Whereas, in the case of Goat hooves, a different trend was observed for $\mathrm{Mn}^{2+}$ ions as increased concentration resulted to decreased amount adsorbed by the substrate. This observation is similar to what was reported by[14].

Further more, comparing the adsorption process of both substrates, it could be deduced that the adsorption of $\mathrm{Pb}^{2+}$ ion from the aqueous solution was more efficient than that of $\mathrm{Mn}^{2+}$ ion. This is probably due to the effect of the size of the hydrated ions like $\mathrm{Pb}^{2+}$ ion which became smaller than $\mathrm{Mn}^{2+}$ ion when hydrated and as such is less susceptible to stearic hindrance. This is in agreement with the research conducted by[8].

Also, from the results obtained shown in Figure 5 and 6, it was observed that the keratinous substrate (Goat hooves) adsorbed more of $\mathrm{Pb}^{2+}$ ions than the cellulosic substrate (Caryota rumphiana flower). This believes to be due to the presence of --SH group on the keratinous substrate. On the other hand, the cellulosic material adsorbed more of $\mathrm{Mn}^{2+}$ ions than the keratinous substrate. This might probably be due to the presence of functional groups with high affinity for $\mathrm{Mn}^{2+}$ ion in the cellulosic substrate than it is present in the keratinous substrate.

Table 1 presents the Freundlich constant $\mathrm{K}_{\mathrm{f}}$ obtained from the Freundlich isotherm represented in Figures 7 to 10 and the maximum uptake for both metal ions using the different substrates. The $\mathrm{K}_{\mathrm{f}}$ which represents the adsorption capacity indicates a higher capacity for $\mathrm{Pb}^{2+}$ using the keratinous substrate with a value of 7.585 than with the cellulosic substrate with a adsorption capacity of 3.311 for $\mathrm{Mn}^{2+}$ ion was observed using the cellulosic substrate than with the keratinous substrate. Also, the $\mathrm{K}_{\mathrm{f}}$ value of $\mathrm{Pb}^{2+}$ ion in both cases is greater than that of $\mathrm{Mn}^{2+}$ ion, confirming that $\mathrm{Pb}^{2+}$ ion has greater absorptivity than $\mathrm{Mn}^{2+}$ ion. Again, this is probably due to the effect of the size of the hydrated ions like $\mathrm{Pb}^{2+}$ ion which became s maller than $\mathrm{Mn}^{2+}$ ion when hydrated and as such is less susceptible to stearic hindrance[14]. The values of correlation coefficient $\mathrm{R}^{2}$ indicated that the adsorption process conforms to the Freundlich isotherms [15]. This as a result of the $R^{2}$ value which was greater than 0.900 in both substrates hence the adsorption was more of multi layered and physiosorption type than uni-molecular layer[16]. The value of $1 / \mathrm{n}$ which was greater 0.700 but less than 1 indicates that $\mathrm{Pb}^{2+}$ and $\mathrm{Mn}^{2+}$ were favourably adsorbed by the substrates. A smaller value of $1 / \mathrm{n}$ indicates better adsorption mechanis $m$ and formation of relatively stronger bond between adsorbate and adsorbent[17][18].

Table 1. Freundlich isotherm constants for the Caryota rumphiana flower and Goat hooves onPb (II) and $\mathrm{Mn}$ (II) adsorption

\begin{tabular}{ccccc}
\hline Adsorbent /metal ion in solution & $\mathrm{q}_{\max }$ & $\mathrm{K}_{\mathrm{f}}$ & $1 / \mathrm{n}$ & $\mathrm{R}^{2}$ \\
\hline Caryota numphiana flower/ $\mathrm{Pb}(\mathrm{II})$ & 11.635 & 4.197 & 0.8735 & 0.9992 \\
Caryota numphiana flower/Mn(II) & 7.32 & 3.450 & 0.7447 & 0.9582 \\
Goat hooves / $\mathrm{Pb}(\mathrm{II})$ & 11.932 & 7.585 & 0.9772 & 0.9992 \\
Goat hooves/ Mn(II) & 3.450 & 1.654 & 0.8032 & 0.9090 \\
\hline
\end{tabular}

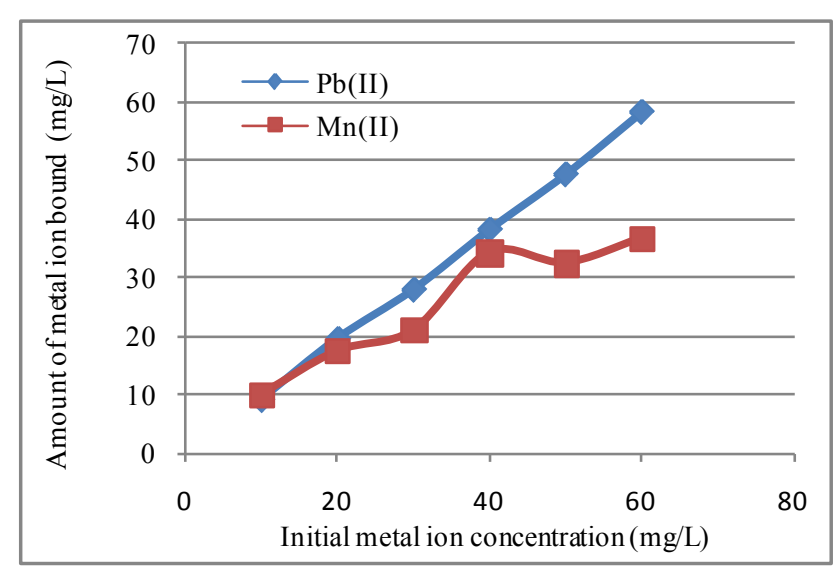

Figure 5. The effect of varying $\mathrm{Pb}$ (II) and $\mathrm{Mn}$ (II) ion concentration on the adsorption of Caryota numphiana flower 


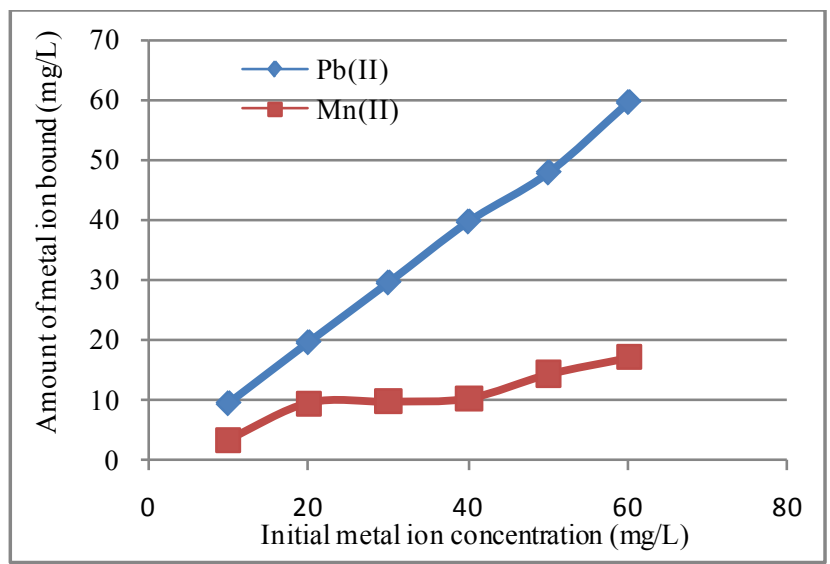

Figure 6. The effect of varying $\mathrm{Pb}$ (II) and $\mathrm{Mn}$ (II) ion concentration on the adsorption of Goat hooves

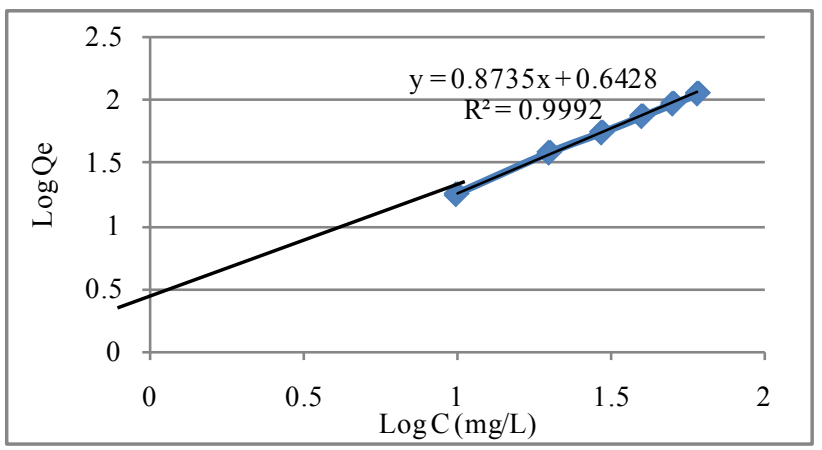

Figure 7. Freundlich isotherm for the adsorption of $\mathrm{Pb}$ (II) ion by Caryota rumphiana flower

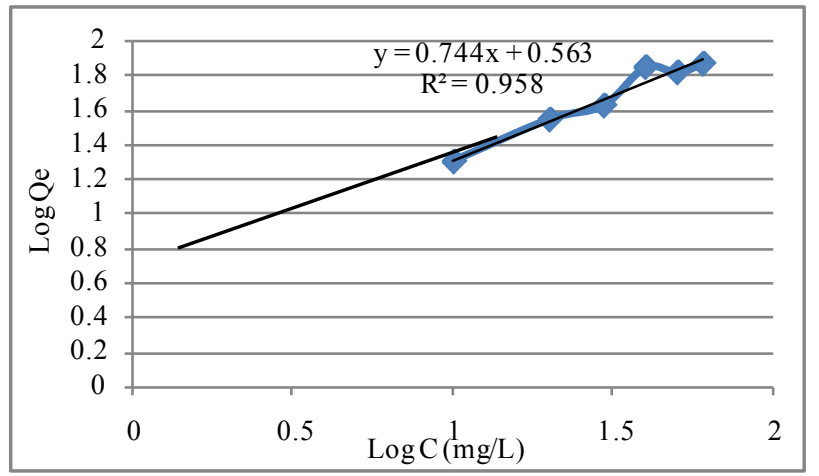

Figure 8. Freundlich isotherm for the adsorption of Mn (II) ion by Caryota rumphiana flower

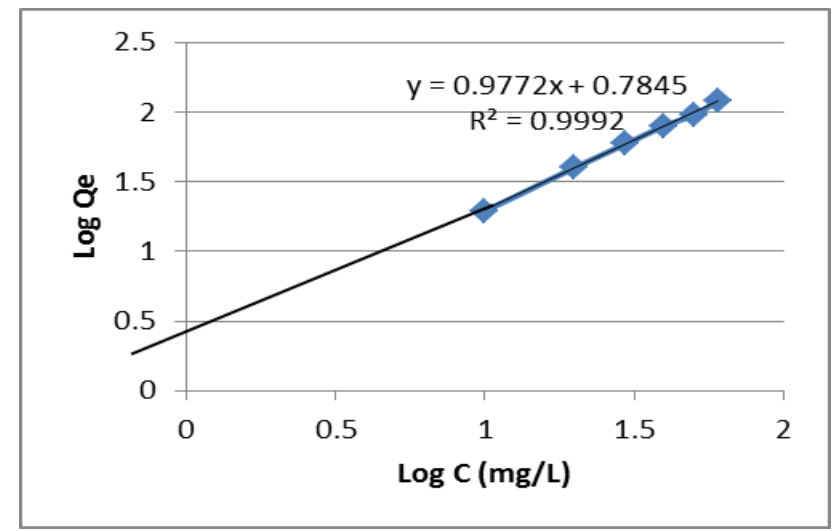

Figure 9. Freundlich isotherm for the adsorption of $\mathrm{Pb}$ (II) ion by Goat hooves

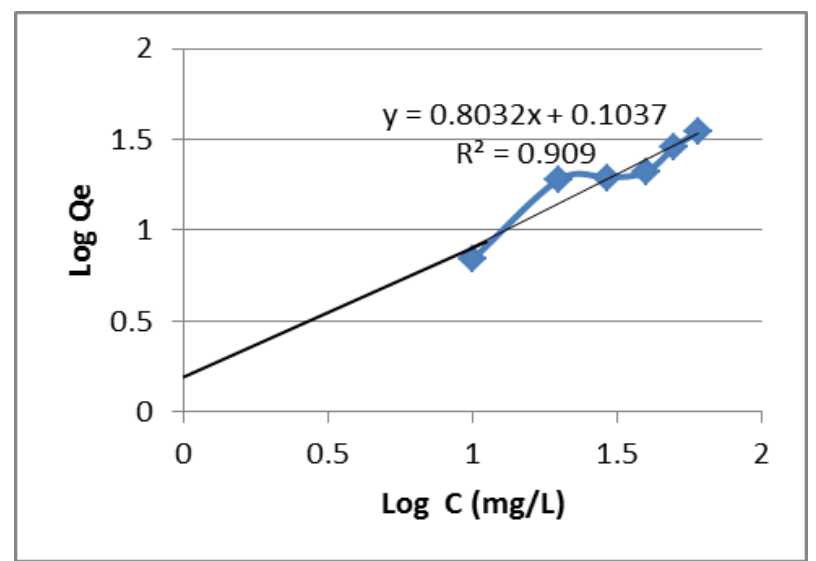

Figure 10. Freundlich isotherm for the adsorption of Mn (II) ion by Goat hooves

\section{Conclusions}

In this study, Caryota rumphiana flower powder and Goat hooves powder were used to adsorbed lead and manganese ions from aqueous solution. Batch experiments showed that the adsorption process was dependent on both contact time and initial metal ion concentration. Using both substrates, equilibrium was established at 60 and 120 minutes for lead and manganese ions respectively. Adsorption of lead ion by the keratinous substrate was more efficient than with the cellulosic substrate while the cellulosic substrate was more effective for the sorption of manganese ion than with the keratinous substrate. The Freundlich isotherm fitted the equilibrium data for the both substrates. Finally, the preliminary study indicated a potential for the use of Caryota rumphiana flower powder and Goat hooves powder in the removal of heavy metals from aqueous solution.

\section{REFERENCES}

[1] Jimoh, T. Preconcentration and Removal of Heavy Metals from Aqueous Solution by African Spinach (Amaranthus hybridus L) stalk and Pawpaw (Carica papaya) seeds (Unpublished Masters thesis submitted to Postgraduate School, Federal University of Technology, Minna, Nigeria for the Award of Master of Technology in Analytical Chemistry). 2010

[2] Kurniawan, T.A. Comparative of low-cost adsorbents for treating waste water laden with heavy metals. Science Total Environment. 366(2-3), 407-424, 2006a

[3] Kurniawan, T.A. Physico-chemical treatment technique for the treatment of water laden with heavy metals. Chemical Engineering Journal, 118(1-2): 83-98, 2006b

[4] Kurniawan, T.A. Physico-chemical treatment for removal of recalcitrant contaminats from landfill leach ate by a combination of advanced oxidation process and granular activated carbon adsorption, PhD Dissertation. 2006c

[5] Afkhami. A., T. Madrakin, Z. Karimi. Effect of the impreg- 
nation of carbon with ethylenediamintetraaceticacid on its adsorption capacity for the adsorption of several metals ions. J. Hazard. Material., 150, 408-412, 2008

[6] Nasim Ahmad Khan., Shaliza, Ibrahim, Piara, Pakran Subramaim. Elimination of heavy metals from wastewater using agricultural waste as adsorbent. Malaysian Journal of Science, 23, 43-51, 2004

[7] Qi. B.C., C. Alderich. Biosorption of heavy metals from aqueous solution by Tobacco dust. Journal of Bioresource Technology, 99(13), 595-601, 2008

[8] Oyebamiji Babalola. J., N..A. Adesola., O. Babarinde, A. Popoola, O.Vincent, O. Oninla. Kinetic, equilibrium and thermodynamic studies of the biosorption of $\mathrm{Cd}(\mathrm{II})$ and $\mathrm{Pb}$ (II) ions from aqueous solution by Tallinium triangulare (water leaf). The Pacific Journal of Science and Technology, 10(1): 428-436, 2009

[9] Kennam, N., T. Veemaraj. (2010). Detoxification of toxic metal ions by sorption to activated carbon from Hevea brasiliensis bark. A comparative study. Global NEST Journal, 10(10), 20, 2010

[10] Okuo., J.M., P.O. Okolo. Removal of Cobalt, Nickel and Cadmium from aqueous solution using a blend of coconut husk, palm cannel fiber and periwinkle shell. Journal of Chemical Society of Nigeria, 2(1), 70-77, 2006

[11] Igwe, J.C., A.A. Abia. A bio-seperation process for removing heavy from waste using iosorbents. African Journal of Biotechnology, 5, 1167-79, 2005

[12] Mahvi, A.H. Application of agricultural fibers in pollution removal from aqueous solution. International Journal of Environmental Science Technology, 5(2), 275-285, 2008

[13] Qaiser Suleiman, Anwar R. Saeemi, Mohammad Mahmood Ahmad. Heavy metal uptake by agro based materials. Electronic Journal of Biotechnology, 10(3), 25, 2007

[14] Rafika Souag, Djilali Touaibia, B. Benchreit, B. Ali. Algerian sheep hooves for the removal of heavy metals from aqueous solution. European Journal, 35(3), 416-465, 2009

[15] Salam A, Adekola FA. The influence of $\mathrm{pH}$ and adsorbent concentration on adsorption of lead and zinc on a natural goethite. Afr. J. Sci. Technol. 5(6), 55-66, 2005

[16] Qaiser S, Anwar RS, Mohammad MA. Heavy metal uptake by agro based materials. Electronic Journal of Biotechnology, 10(3), 25, 2007

[17] Patil S, Bhole A, Natrajan G. Scavenging of Ni(II) Metal Ions by Adsorption on PAC and Babhul Bark. J. Enviroment, Sci. Eng., 48 (3), 203-208, 2006

[18] Saifudd in M, Nomanb H, Kumaran P (2005). Removal of heavy metals from industrial waste water using chitosan coated oil palm shell charcoal. Electronic J. Biotechnol., 8(1): 20-30 